\title{
Estimation of water quality of Sava River (Vojvodina, Serbia) in the period 2004-2011 using Serbian Water Quality Index (SWQI)
}

\author{
Dajana Bjelajac ${ }^{A B}$, Igor Leščešen ${ }^{A}$, Tanja Micić ${ }^{A}$, Milana Pantelić ${ }^{B}$ \\ Received: September 2013 | Revised: December 2013 | Accepted: December 2013
}

\begin{abstract}
A Water Quality Index (WQI) is a numeric expression used to evaluate the quality of water bodies and make it easier understood by managers. This paper aims to assess water quality of Sava River in Vojvodina (North Serbia) for the 2004- 2011 period. For this purpose authors applied: Serbian Water Quality Index (SWQI) assessment. WQI value is dimensionless, single number ranging from o to 100 (best quality) derived from numerous physical, chemical, biological and microbiological parameters. For the Sava River SWQI was mainly rated as very good. This study shows a clear decrease in water quality during warmer periods of the year. Additionaly, this study shows that water quality along Sava River decreases slightly downstream, of Sremska Mitrovica station but it still provides values that according to SWQI descriptive quality indicator have been defined as good (72-83) and very good (84-89). Also, this study shows an increase of SWQI downstream of the confluence of Drina River into Sava River. This methodology includes parameters for assessment of organic loading, but does not involve parameters of heavy metals concentration.
\end{abstract}

Key words: SWQI, Sava River, Serbia, water quality

\section{Introduction}

Water quality is one of the most significant factors that have to be taken into account in evaluation of sustainability of a particular region (Córdoba et al., 2010). The important aspects taken into consideration when examining the top-priority problems of water quality are the economic influence, the influence on human health, the influence on the ecosystem, the influence of the geographic area as well as the duration of the influence (Dalmacija, 2004).

The quality of the watercourse at any of the points depends on several key influences: basin lithology, atmospheric influences, climatic conditions and anthropogenic influences (Shrestha, Kazama, 2007). River systems play an important role in the sustaina- ble development of the entire environment, especially if they flow through inhabited areas (Kowalkowski et al., 2006). In order to provide the sustainability of ecological balance, the presence and quality of water are very important (Karadavut et al., 2011) and there have been more researches based upon water quality observing (Parvulescu, Hamchevici, 2010). Anthropogenic influences can cause negative consequencies in short period of time as far as water quality is concerned (Yunus, Nakagoshi, 2004), whereas waterbody pollution represents the result of human activities on one hand, and intensive urbanization development on the other hand (Dragićević et al., 2010). The organic solid load and the dynamics of its degradation are very good indicators of the anthropogenic im-

A University in Novi Sad, Serbia Faculty of Science, Department of Geography, Tourism and Hotel Management, Dositeja Obradovića 3, 21000 Novi Sad, Serbia

B Climatology and Hydrology Research Centre, Faculty of Science, University of Novi Sad, Trg Dositeja Obradovića 3, 21000 Novi Sad, Serbia

* Corresponding author: Dajana Bjelajac, dajana.bjelajac92@gmail.com 
pact on the waters (Gurzau et al., 2010). Sava River is, like many other rivers in developing countries, polluted because of anthropogenic influences, mostly due to release of industrial and sewer system waste water directly in water ecosystems.

Water Quality index attempts to provide a mechanism for presenting a cumulatively derived numerical expression defining certain level of water quality (Miller et al, 1986), and is useful for comparative purposes and when general questions are addressed (Hallock, 2002, Bordalo et al, 2006). In this study, the water quality status as well the spatial and temporal trends over eight year period (2004-2011) were assessed to four different locations on Sava River.

\section{Material and methods}

\section{Sampling Area}

The Sava River stretches 940 kilometers along the South-Eastern Europe. Area Basin is $95720 \mathrm{~km}^{2}$ and it extends into parts of Slovenia, Croatia, Bosnia and Herzegovina, Montenegro, Albania and Serbia. It is made of two spring branches, Save and Save Dolinke Bohinjka which unite about 9oom upstream from the town of Bled. It is a right tributary of the Danube (Dukić, 1975).

Through almost whole lenght of a stream, river bed of Sava lies on its own fluvial deposits. In Pannonian basin Sava meandres through wide area, making meandres such as Bosutsko, Savin Bok etc. The flow riches its maximum width at measure station Šabac.

\section{Data and Methods}

Database of Republic Hydrometeorological Service for period 2004-2011 (RHMS, 2011) was used to present the existing state of water quality of Sava river.Parameters of physical, chemical, biological and microbiological water quality were measured at the four control point on Sava River: Jamena, Sremska Mitrovica, Šabac and Ostružnica during period 2004-2011.

Serbian Water Quality Index (SWQI) was used for description of water quality. This system of surface waterbodies quality description represents the way of quality estimation for certain parameteres group, where earlier researches and studies show that this method ensures general overwiev of surface water quality at certain place (Veljković, 200oa; Veljković 2001; Veljković 2003; Đurašković \& Vujović, 2004; Veljković, 2007; Đurašković \& Tomić, 2009; Pantelić et al., 2012; Leščešen et al., 2013). This method is based upon the fact that ten chosen parametres (oxygen saturation, $\mathrm{BOD}$, ammonium, $\mathrm{Ph}$ value, total oxidised nitrogen, orthophospates, suspended solids, temperature, conductivity and coliform bacteria) with their quality (qi) represent features of surface water reducing them at one index number. Influence of each of ten chosen parametres on general water quality is not the same, so that each of them was assigned the wieght (wi) and score of points according to their contribution to water quality endangering. The result (qixwi) gives the index100, as an ideal summation of weights of all parametres (Oregon Water Quality Index Summary Report, 1996-2005). Index points from o to 100 will be assigned to particular waterbody according to

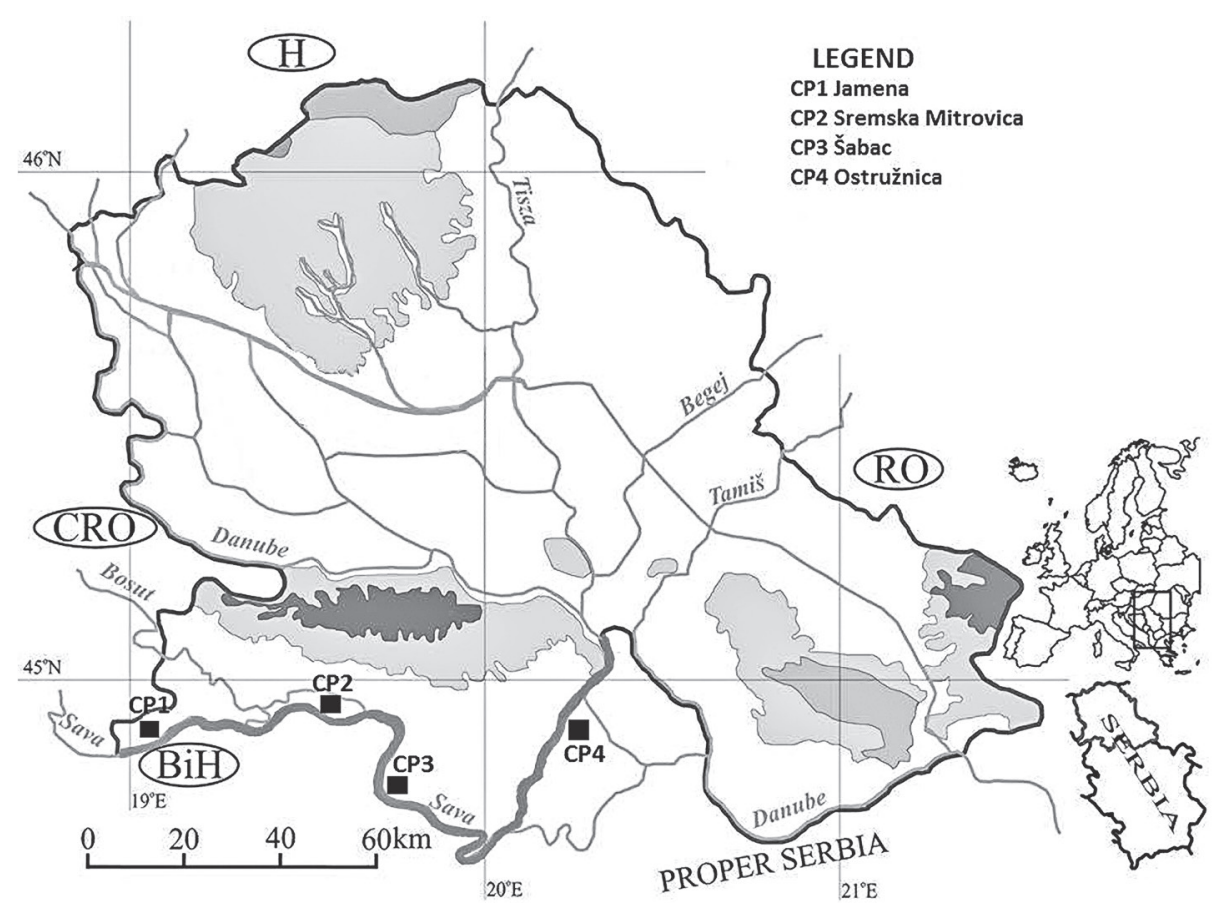

Figure 1. Geographical location of the research area and measuring stations at Sava River 
the points assigned to particular parametres (Pantelić et al., 2012; Leščešen et al., 2013). Formula used for SWQI calculation is:

$\mathrm{SWQI}=0,18 \% \mathrm{O}_{2}+0,15 \mathrm{BPK}_{5}+0,12 \mathrm{NO}_{4}+0,09 \mathrm{pH}$

$+0,08 \mathrm{~N}+0,08 \mathrm{PO}_{4}+0,07 \mathrm{SM}+0,05 \mathrm{t}+0,06 \mu \mathrm{S}+$

$0,12 \mathrm{MPN}$

Descriptive quality indicator have been defined for each SWQI values ranging from very poor (o-38), poor (39-71), good (72-83), very good (84-89), and excellent (90-100). Main limitation for SWQI is relative small number of parameters. Used parameters provide information about organic loading, but not about heavy metal pollution. Also, SWQI can be calculated even in a case of missing some values. Since there is no single, universal parameter that properly describes surface waterquality, investigators typically use several indicators related to sanitary quality, ability to sustain aquatic life, ecosystem productivity and aesthetics (Pharino, 2007).

\section{Results}

Average values of ten water quality parameters for all four control points are presented in table 1. Monthly values of these parameters were used to calculate SWQI for Sava River. Temperature varies from minimum $13,39^{\circ} \mathrm{C}$ at $\breve{a} a b a c$ to $14,95^{\circ} \mathrm{C}$ at Ostružnica station. The water acidity measures from 7,88 till 7,99. Highest average conductivity was recorded on Jamena station 409,07 $\mu \mathrm{S} \mathrm{cm}-1$. Average Oxygen saturation for research period is $91,7 \%$ with highest value measured at Sremska Mitrovica station (94,35\%) and lowest value at Jamena station $(88,86 \%)$. Biochemical oxygen demand is used as a measure of organic wasteload strength, and on Sava River, it varies from 1,26 $\mathrm{mg} / \mathrm{l}$ on Sremska Mitrovica station till 2,22 $\mathrm{mg} / \mathrm{l}$ on Ostružnica station. Another important indicator of water quality is the amount of solids in the water column - both dissolved (filterable) solids and not dissolved (suspended) solids (Pharino, 2007). Suspended solids show progressive decrease from Jamena station $(20,40 \mathrm{mg} / \mathrm{l})$ till Šabac station $(15,66 \mathrm{mg} / \mathrm{l})$, slightly higher values are measured at Jelav station $(15,78$ $\mathrm{mg} / \mathrm{l})$. Total oxidiesed nitrogen values for Sava River vary from 1,37 mg/l at Sremska Mitrovica station, till its highest value at Ostružniva station $1,58 \mathrm{mg} / \mathrm{l}$. Highest values of orthophospates during 2004- 2011 period is measured at Ostružnica station $(0,32 \mathrm{mg} / \mathrm{l})$. Amonium values varry from lowest values measured at Sremska Mitrovica and Šabac stations (o,03 mg/l) till its highest value measured at Ostružnica station $(0,06 \mathrm{mg} / \mathrm{l})$. Values of coliform bacteria rise continuously from Jelav station (2159 n/l), Sremska Mitrovica station $(2306 \mathrm{n} / \mathrm{l})$ with highest values at Šabac station

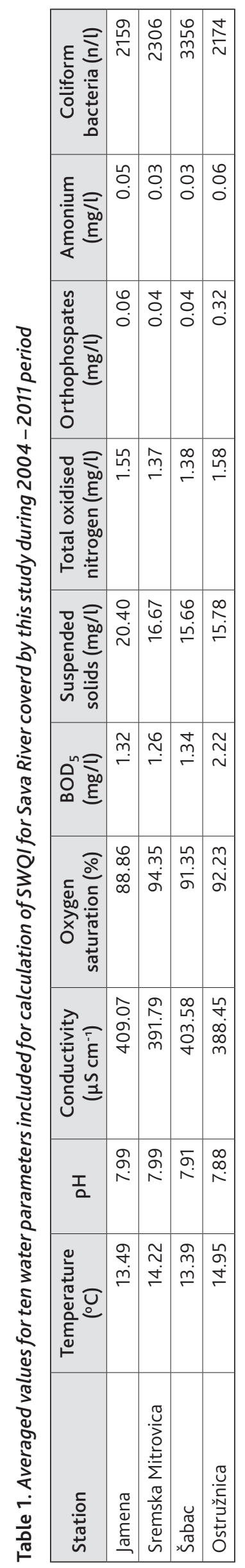


Table 2. Monthly values of SWQI for Jamena station

\begin{tabular}{|c|c|c|c|c|c|c|c|c|}
\hline SWQI & 2004 & 2005 & 2006 & 2007 & 2008 & 2009 & 2010 & 2011 \\
\hline I & 86 & 91 & 82 & 86 & 81 & 86 & 88 & 90 \\
\hline II & 86 & 83 & 86 & 85 & 89 & 90 & 74 & 80 \\
\hline III & 86 & 81 & 88 & 87 & 85 & 85 & 90 & 89 \\
\hline IV & 90 & 89 & 90 & 90 & 84 & 83 & 87 & 91 \\
\hline V & 93 & 88 & 88 & 91 & 89 & 83 & 81 & 85 \\
\hline VI & 85 & 78 & 90 & 85 & 82 & 87 & 74 & 74 \\
\hline VII & 86 & 81 & 81 & 85 & 81 & 88 & 83 & 84 \\
\hline VIII & 84 & 82 & 82 & 85 & 82 & 86 & 79 & 81 \\
\hline XIX & 83 & 85 & 78 & 87 & 81 & 81 & 75 & 82 \\
\hline$X I X$ & 84 & 82 & 86 & 80 & 80 & 87 & 90 & 86 \\
\hline XIX & 83 & 81 & 91 & 89 & 83 & 80 & 89 & 88 \\
\hline XII & 89 & 74 & 80 & 90 & 72 & 86 & 89 & 83 \\
\hline Average & 86 & 83 & 85 & 87 & 82 & 85 & 83 & 84 \\
\hline
\end{tabular}

$(3356 \mathrm{n} / \mathrm{l})$, on Ostružnica station the value the value of coliform bacteria is second lowest (after Jamena) and measures $2174 \mathrm{n} / \mathrm{l}$.

SWQI was calculated 96 times throughout eight years for Jamena station (table 2) and ranged from 82 in 2008 to 87 in 2007. According to obtained results, water quality of Sava River at Jamena station could be classified as very good (84-89).

SWQI was calculated 96 times for Sremska Mitrovica station during this eight year period (Table 3). Values ranged from lowest 86 (2004) to 89 (2010). Accordin to these results water quality at Sremska Mitrovica station can be classified as very good for the the whole investigated period.

SWQI was calculated 96 times for Šabac station (Table 4) and ranged on average from 85 in 2005 to 90 in 2010. On this station for the first time in research period were observed values according to whic water quality could be classefied as excelent, 90 in 2011.
Generally, water quality at Šabac station can be classified as very good (2004, 2005, 2006, 2007, 2008, 2009 and 2010) and excelent (2011).

For Ostružnica station SWQI was calculated 95 times on monthly basis for eight years. Its values ranged from 82 in 2005 to 88 in 2011 . The monthly results are represented in table 5 . In the results only one data is missing for the entire research period, december of 2011 ( - , in table). Water quality of Sava River at Ostružnica station can be classified as very good.

Values of SWQI for research period 2004 to 2011 are presented on Figure 2. We can see that on average the highest values are measured on Sremska Mitrovica and Šabac stations (bouth 87). For Ostružnica station average value of SWQI for eight year period is 85 and the lowest value of SWQI were observed at Jemna station (85). These values indicate that the quality of water in Sava River, according to SWQI can be classified as very good (84-89).

Table 3. Monthly values of SWQI for Sremska Mitrovica station

\begin{tabular}{|c|c|c|c|c|c|c|c|c|}
\hline SWQI & 2004 & 2005 & 2006 & 2007 & 2008 & 2009 & 2010 & 2011 \\
\hline I & 85 & 92 & 86 & 89 & 89 & 89 & 86 & 89 \\
\hline II & 89 & 91 & 92 & 86 & 91 & 90 & 90 & 92 \\
\hline III & 85 & 89 & 86 & 89 & 91 & 89 & 94 & 93 \\
\hline IV & 85 & 88 & 86 & 91 & 89 & 91 & 90 & 93 \\
\hline V & 90 & 92 & 86 & 89 & 91 & 87 & 94 & 90 \\
\hline VI & 85 & 88 & 90 & 83 & 85 & 88 & 82 & 83 \\
\hline VII & 85 & 77 & 86 & 86 & 83 & 84 & 86 & 84 \\
\hline VIII & 85 & 83 & 83 & 84 & 84 & 85 & 85 & 85 \\
\hline XIX & 83 & 82 & 84 & 88 & 88 & 86 & 88 & 90 \\
\hline XIX & 85 & 90 & 89 & 85 & 84 & 88 & 90 & 89 \\
\hline XIX & 85 & 88 & 91 & 88 & 93 & 82 & 90 & 91 \\
\hline XII & 86 & 88 & 88 & 90 & 86 & 85 & 89 & 83 \\
\hline Average & 86 & 87 & 87 & 87 & 88 & 87 & 89 & 88 \\
\hline
\end{tabular}


Table 4. Monthly values of SWQI for Šabac station

\begin{tabular}{|c|c|c|c|c|c|c|c|c|}
\hline SWQI & 2004 & 2005 & 2006 & 2007 & 2008 & 2009 & 2010 & 2011 \\
\hline I & 85 & 91 & 85 & 87 & 91 & 84 & 89 & 91 \\
\hline II & 89 & 90 & 85 & 88 & 93 & 90 & 89 & 91 \\
\hline III & 90 & 82 & 86 & 89 & 90 & 89 & 93 & 90 \\
\hline IV & 90 & 89 & 89 & 91 & 88 & 90 & 90 & 90 \\
\hline V & 92 & 89 & 86 & 92 & 92 & 86 & 93 & 90 \\
\hline VI & 84 & 85 & 88 & 87 & 85 & 87 & 86 & 86 \\
\hline VII & 85 & 73 & 84 & 83 & 84 & 85 & 83 & 86 \\
\hline VIII & 83 & 77 & 84 & 87 & 87 & 88 & 85 & 86 \\
\hline IX & 86 & 80 & 86 & 90 & 90 & 86 & 89 & 88 \\
\hline$x$ & 87 & 88 & 85 & 85 & 87 & 86 & 85 & 90 \\
\hline$X I$ & 83 & 89 & 89 & 90 & 90 & 83 & 90 & 91 \\
\hline XII & 90 & 86 & 91 & 91 & 89 & 89 & 91 & 89 \\
\hline Average & 87 & 85 & 85 & 88 & 89 & 87 & 89 & 90 \\
\hline
\end{tabular}

Table 5. Monthly values of SWQI for Ostružnica station

\begin{tabular}{|c|c|c|c|c|c|c|c|c|}
\hline SWQI & 2004 & 2005 & 2006 & 2007 & 2008 & 2009 & 2010 & 2011 \\
\hline I & 80 & 90 & 85 & 85 & 86 & 90 & 93 & 93 \\
\hline II & 83 & 84 & 85 & 93 & 90 & 89 & 92 & 91 \\
\hline III & 91 & 78 & 83 & 86 & 82 & 84 & 86 & 89 \\
\hline IV & 88 & 84 & 83 & 88 & 83 & 93 & 87 & 86 \\
\hline V & 92 & 90 & 89 & 84 & 88 & 84 & 90 & 79 \\
\hline VI & 83 & 83 & 82 & 80 & 81 & 78 & 84 & 89 \\
\hline VII & 76 & 76 & 64 & 85 & 79 & 86 & 76 & 85 \\
\hline VIII & 78 & 66 & 81 & 83 & 85 & 84 & 81 & 86 \\
\hline XIX & 80 & 76 & 80 & 78 & 86 & 85 & 88 & 90 \\
\hline XIX & 93 & 84 & 92 & 82 & 91 & 92 & 88 & 91 \\
\hline XIX & 83 & 88 & 85 & 84 & 85 & 88 & 88 & 89 \\
\hline XII & 93 & 89 & 89 & 86 & 83 & 76 & 90 & - \\
\hline Average & 85 & 82 & 83 & 84 & 85 & 86 & 87 & 88 \\
\hline
\end{tabular}

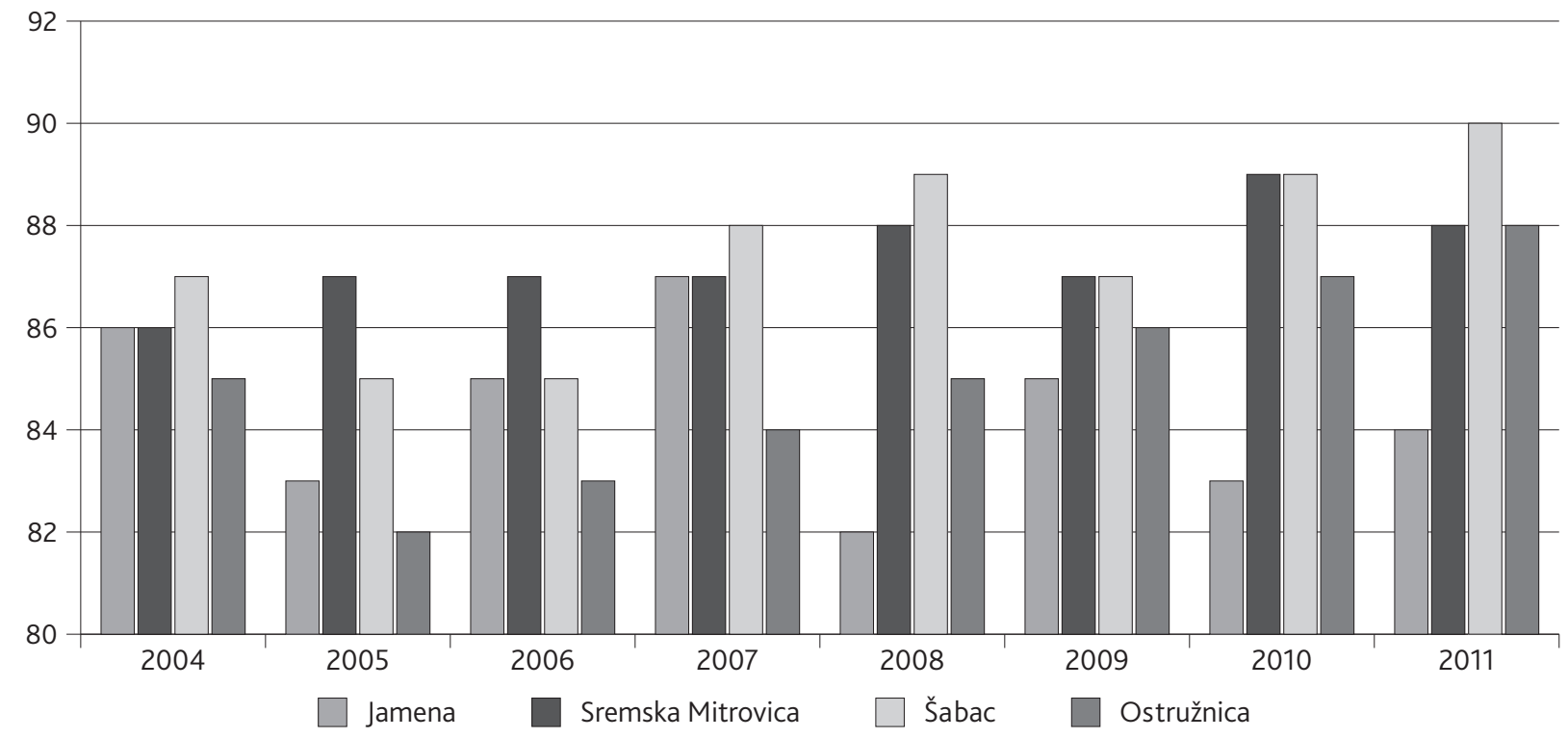

Figure 2. Average values of SWQI for Sava river per year 


\section{Discussion}

The water quality status, the spatial and temporal trends along Sava River were assessed through the application of ten parameter SWQI, to a eight year public database of environmental data. In the case of Sava River it should be stated that the index is not adopted to a specific use, such as bathing water or fish spawning, but rather producing a general index to determine the overall water quality.

According to the SWQI, water quality of Sava River in Serbia during period 2004-2011, was assessed very good. Values of SWQI for research period fluctuate from 85 to 87 . Both values are classified according to SWQI descriptive quality indicator as very good (8489). However, these results should be accepted as questionable, because SWQI gives information about organic loading, but not about heavy metals pollution. Along $206 \mathrm{~km}$ stretch of the Serbian part of Sava River, the water quality droped modestly but steadily downstream.

The control point Jamena had the lowest mean value SWQI (85).It is observed that the quality of the water quality increases downstream from control point Jamena to the mouth of the Danube River. The reason for increased SWQI is the inflowing of the Drina River in Sava River near the town of Sremska Rača. Based on SWQI, water quality of Drina River was classified as excellent (93) (Leščešen et al.,2013). Largest value is recorded at the measuring stations Sremska Mitrovica and Šabac (87), which are located relatively near the confluence of the Drina and Sava River. On the fourth control point Ostružnica is recorded a decline in the value of SWQI.On the value results big impact has waste water coming from two of the largest settlements upstream from the control point OstružnicaSremskaMitrovica and Šabac.

Temperature can also have influence on water quality. If water tempereature in river is higher, there is intensive biological activity and dissolved oxygen concentration lessens (Sanchez, 2007). Sesonal variance in water quality was observed and some patterns were noticed on all four stations. Lowest values o SWQI were observed at all stations during June, July, August and September. On the Jamena station, average water quality index for June during 2004-2011 period is 82, July 84, August 83 and September 81 and the air temperatures for these mounths on average are more than 200 Celsius. Values for months June, August and September are according to SWQI nomenclature classified as good.Although the values of SWQI were on average higher then on Jamena station the same patern was observed on othet three stations (Sremska Mitrovica, Šabac and Ostružnica). On Sremska Mitrovica and Šabac stations values of SWQI are classefied as very good), but on Ostružnica station, we can see that values of SWQI again can be classefied as good during these months (June, July, August and Septembar). From these data, we can conclude that water quality of Sava River is worse in warmer period of the year. Numerous researches stated the same trend, Suquia River, Argentina (Pesce \& Wunderlin, 200o), Odzi River, Zimbabwe (Jonnalagadda \& Mhere, 2001), Bangpakong River, Thailand (Bordalo et al., 2001), San Vicente Bay, Chile (Rudolf et al., 2002), Pampa Murillo, Mexico (Herna'ndez-Romero et al., 2004), Veliki Bački kanal, Serbia (Pantelić et al, 2012), Drina River (Leščešen et al., 2013).

\section{Conclusion}

This study shows the importance of applying a WQI that reflects the collectiv influence of various criteria and allows easy interpretation of data from monitoring networks. Additionaly, this study shows that water quality along Sava River decreases slightly downstream, but it still provides values that according to SWQI descriptive quality indicator have been defined as good (72-83) and very good (84-89). Based on the results of the study that analysed the impact of ten parameters measured on four control points during 2004-2001 period on water quality of the Sava River it has been established that natural factors, primarily water temperature affect changes in water quality throughout the years. Although the anthropogenic impact on the quality of river is far more intensive, this study has established that natural factors may affect the increase or reduction of Water Quality Index throughout the investigated period up to a certain extent. This study has shown that other rivers influence changes of SWQI. In the case of Sava River it was shown that Drina River has a great influance on water quality downstream of its confluence into Sava River.

\section{References}

Bordalo A. A., Teixeira, R., William, J. W. 2006. A Water Quality Index Applied to an International Shared River Basin: The case study of the Duro River. Environ Manage 38:910-920.

Bordalo, A. A., Nilsumranchi, W. \&Chalermwat, K. 2001. Water quality and uses of the Bangpakong River (Eastern Thailand). Water Research, 35, 35353642.

Córdoba E. B., Martínez A. C., Ferrer E. V., 2010. Water quality indicators: Comparison of a probabilistic index and a general quality index. The case of the Confederación Hidrográfica del Júcar (Spain). Ecological Indicators 10 (5), 1049-1054.

Dalmacija, B. \&Tumbas-Ivančev I. 2004. Water analysis - quality control, results interpretation. Facul- 
ty of Sciences, Department of Chemistry, Novi Sad. [In Serbian]

Dragićević, S., Nenadović S., Jovanović B., Milanović M., Novković I., Pavić D. \&Lješević M. 2010. Degradation of Topciderska river water quality (Belgrade).Carpathian Journal of Earth and Environmental Sciences, 5, 2, 177-184.

Đurašković, P. N. \&Tomić, N.2009. Skadar Lake Water Quality by WQI Method.Conference "Zastitavoda o9", Zlatibor, Serbia. [In Serbian]

Ferenczi, L. \&Balog, A.2010. A pesticide survey in soil, water and foodstuffs from central Romania. Carpathian Journal of Earth and Environmental Sciences, 5, 1, $111-118$.

Gavrilović, Lj., Dukić, D. 2002. Rivers of Serbia, Institute for Textbooks, Belgrade, [In Serbian]

Gurzau, A.E., Popovici, E., Pintea, A., Popa, O., Pop, C. \&Dumitrascu I.2010. Quality of surface water sources from a central transylvanian area as a possible problem for human security and public health. Carpathian Journal of Earth and Environmental Sciences, 5, 2, $119-126$.

Hallock, O. 2002. A water quality index for ecology's stream monitoring program. Washington State Department of Ecology, Olympia WA. Publication No 0203052, 23p

Herna'ndez-Romero, A. H., Tovilla-Herna'ndez, C., Malo, E. A. \& Bello-Mendoza, R. 2004. Water quality and presence of pesticides in a tropical coastal wetland in southern Mexico. Marine Pollution Bulletin, 48, 1130-1141.

Jonnalagadda, S. B. \&Mhere G.2001. Water quality of the Odzi River in the Eastern highlands of Zimbabwe. Water Research, 35, 2371-2376.

Jonnalagadda, S. B. \&Nenzou G., 1996. Studies on arsenic rich mine dumps: I Effect on the terrestrial environment. Journal of Environmental Science and Health: Part A, 31, 8, 1909 - 1915.

Jonnalagadda, S. B., Mathuthu A. S. \&Odipo R. W., 1991. River pollution in developing coimtries, a case study III : Effect of industrial discharges on quality of Ngong river waters in Kenya. Bulletin of the Chemical Society Ethiopia, 5, 49-64.

Karadavut, I.S., Saydam A. C., Kalipci E., Karadavut S. \&Özdemir C.2011. A research for water pollution of Melendiz stream in terms of sustainability of ecological balance. Carpathian Journal of Earth and Environmental Sciences, 6, 1, 65-80.

Kowalkowski, T., Zbytniewski, R., Szpejna, J., Buszewski, B. 2006. Application of chemometrics in river water classification. Water Research 40 (4), 744-752.

Leščešen, I., Kotrla, S., Otašević, K., Pantelić, M., Josimov, A., Čeperković, M., 2013. Assesment of Water Quality Parametres of Drina River (West Ser- bia) in the Period 2004-2011. European Researcher, 2013, Vol.(61), № 10-2.

Mathuthu, A. S., Zaranyika F. M. \&Jonnalagadda S. B., 1993. Monitoring of water quality in upper Mukuvisi River in Harare, Zimbabwe. Environment International, 19, 51- 61.

Miller, W. W., Joung H. M. \&Mahannah C. N.1986. Identification of water quality differences in Nevada through index application. Journal of Environmental Quality, 15, 265-272.

Oregon Water Quality Index Summary Report, Water Years 1996-2005, Curtis Cude, DEQ Laboratory Division, Water Quality Monitoring Section, USA.

Pantelić, M., Dolinaj, D., Savić, S., Stojanović, V., Nađ, I. 2012. Statistical Analysis of water quality parameters of Veliki Bački Canal (Vojvodina, Serbia) in period 2000-2009. Carpathian Journal of Earth and Environmental Sciences 7 (2), 255-264.

Pârvulescu, L. \&Hamchevici, C.2010. The relation between water quality and the distribution of Gammarusbalcanicusschäferna 1922 (amphipoda: gammaridae) in the anina mountains.Carpathian Journal of Earth and Environmental Sciences, 5, 2, $161-168$.

Pesce, S. F. \&Wunderlin, D. A.200o. Use of water quality indices to verify the impact of Cordoba City (Argentina) on Suquia River. Water Research, 34, 2915-2926.

Pharinp, C. 2007. Sustainable Water Quality Management Policy, Published by Springer, P.O. Box 17, 3300 AA Dordrecht, The Netherlands.

Rudolf, A., Ahumada, R. \&Pe'rez, C.2002. Dissolved oxygen content as an index of water quality in San Vicente Bay, Chile(36 degrees, 450S). Environmental Monitoring and Assessment, 78, 89-100.

Shrestha, S., Kazama, F. 2007. Assessment of surface water quality using multivariate statistical techniques: A case study of the Fuji river basin, Japan. Environmental Modelling and Software 22 (4),464475.

Veljković, N. 200o. Determinig water quality index of the Southern Morava basin by the application of WQI method. Waters Protection 2000, Yugoslav Society for Waters Protection, Belgrade. [In Serbian]

Veljković,N.2001. Measuring indicators of sustainable water development for agglomerations in theSouthMorava basin. 11th Stockholm Water Symposium, Abstract Volume: Building BridgesThrough Dialogue,Stockholm, Sweden.

Yunus, A. J. M. \&Nakagoshi N.2004. Effects of seasonality on streamflow and water quality of the pinang river in Penang Island, Malaysia. Chinese Geographical Science, 14, 2, 153-16. 